\section{Bulb Circumference Influences Growth and Crop Quality in Pineapple Lily}

\author{
Shawn D. Lyons, William B. Miller ${ }^{1}$, H. Christian Wien, and \\ Neil S. Mattson
}

AdDitional INDEX wORDs. bulb blindness, bulb circumference, cut flowers, Eucomis geophyte, specialty crops

Summary. The objective of this study was to determine effects of bulb size on production time and factors influencing crop quality in pineapple lily (Eucomis sp.) cultivars developed originally for cut flower production. The percentage of bulbs producing an inflorescence increased as bulb size increased. One hundred percent of bulbs $>18 \mathrm{~cm}$ circumference flowered in three of the four cultivars whereas 'Tugela Jade' exhibited $\mathbf{8 8} \%$ flowering. The number of flowers per inflorescence increased as bulb size increased. Scape length increased as bulb size increased in 'Reuben'. Inflorescence length increased as bulb size increased in 'Reuben', 'Tugela Jade', and 'Tugela Gem'. Days to anthesis from planting decreased as bulb size increased in 'Reuben' and 'Tugela Jade'. For all cultivars, the largest bulbs produced the greatest number of leaves per plant and the highest quality inflorescences, largely attributable to the larger number of flowers produced per inflorescence compared with smaller bulbs.

$\mathrm{P}$ ineapple lilies are summerflowering bulbs known for their showy, long-lasting inflorescences with a distinct tropical appearance. They are a recent introduction to greenhouse floriculture and, like many other bulbous specialty ornamentals, are currently underused by the industry (Carlson, 2010). A large proportion of the pineapple lily cultivars currently available were originally bred for cut flower production (J. De Goede, personal communication). Several factors that made these cultivars attractive candidates for specialty cut flower production, such as the production of large, showy inflorescences in a wide range of colors, excellent postharvest longevity, and unique appearance are also desirable for potted plant production. Although interest in the crop has increased in recent years, many commercial greenhouse growers are hesitant to produce them because of a lack of production information and other grower resources (Carlson, 2010).

In many geophytes, bulb size plays a major role in determining competency to flower and may affect factors related to crop quality, such as

Horticulture Section, School of Integrated Plant Sciences, Cornell University, 134 Plant Sciences Building, Ithaca, NY 14853

We are grateful to Jack De Goede for supplying plant material.

${ }^{1}$ Corresponding author. E-mail: wbm8@cornell.edu. https://doi.org/10.21273/HORTTECH04053-18 inflorescence size and number of flowers produced per plant (De Hertogh and Le Nard, 1993), but the optimum bulb size for these cultivars has not been determined. The objective of this research was to determine the optimal bulb size for four pineapple lily cultivars [originally bred in New Zealand and derived from tall pineapple lily (Eucomis comosa)] when grown as a potted plants.

\section{Materials and methods}

Year 1. Bulbs of cultivars Megaru, Reuben, and Tugela Gem were received from De Goede Bulb Farm (Mossyrock, WA) on 20 Mar. The bulbs had been lifted from fields in Washington State in late November and stored in open ventilated crates at $\approx 10^{\circ} \mathrm{C}$ before shipment. They were sorted into four size groups (12-14, 14-16, 16-18, and $>18 \mathrm{~cm}$ circumference) with 25 bulbs in each group. On arrival, bulbs were kept at $9^{\circ} \mathrm{C}$ before planting. On 14 Apr., bulbs were planted in $15-\mathrm{cm}$-diameter containers using a commercial peat-based substrate (LM-111; Lambert Peat Moss Co., Riviere-Ouelle, QC, Canada) and moved to a glass greenhouse heated to $17{ }^{\circ} \mathrm{C}$. Measured air temperatures (Onset Computer Corp., Bourne, MA) during the experiment were $21 \pm 5{ }^{\circ} \mathrm{C}$ daytime maxima and $17 \pm 2{ }^{\circ} \mathrm{C}$ nighttime minima. Pots were randomized (completely randomized design was employed) within respective cultivars. Pots were spaced at $25 \mathrm{~cm}$ on center. Once aboveground growth was observed, a commercial $20 \mathrm{~N}-2.2 \mathrm{P}-16.6 \mathrm{~K}$ fertilizer (JR Peters, Allentown, PA) was applied via fertigation at a rate of $150 \mathrm{mg} \cdot \mathrm{L}^{-1}$ nitrogem $5 \mathrm{~d}$ per week. Scape length and leaf length (measured from the rim of the pot to the terminus of the inflorescence or tallest leaf) was recorded for each plant at the onset of anthesis. Days to anthesis were calculated from planting date to anthesis. Once all plants had flowered, stem (pot rim lowest flower in the inflorescence) and inflorescence length (distance from lowest flower to inflorescence apex) and the number of flowers per inflorescence and number of leaves produced by each plant were recorded. The percentage of plants flowering was calculated for each cultivar and bulb size group. Analysis of variance was performed with JMP statistical software (SAS Institute, Cary, NC) to determine significant effects. Where significant differences were found, mean separation comparison was conducted using Tukey's honestly significant difference at $\alpha=0.05$.

Year 2. Bulbs of 'Megaru', 'Reuben', and 'Tugela Jade' were received from De Goede Bulb Farm on 20 Apr. with size groups as in year 1. Bulbs were planted immediately and moved to greenhouse conditions as described previously. Plant care, data collection, and statistical analysis were performed as described previously.

\section{Results}

Year 1. With 'Megaru', the greatest percent flowering was observed in the $>18-\mathrm{cm}$ bulbs $(100 \%)$, whereas the lowest percent flowering

\begin{tabular}{|c|c|c|c|}
\hline \multicolumn{4}{|l|}{ Units } \\
\hline $\begin{array}{l}\text { To convert U.S. to SI, } \\
\text { multiply by }\end{array}$ & U.S. unit & SI unit & $\begin{array}{l}\text { To convert SI to U.S., } \\
\text { multiply by }\end{array}$ \\
\hline $\begin{array}{l}2.54 \\
1 \\
\left({ }^{\circ} \mathrm{F}-32\right) \div 1.8\end{array}$ & $\begin{array}{l}\text { inch(es) } \\
\text { ppm } \\
{ }^{\circ} \mathrm{F}\end{array}$ & $\begin{array}{l}\mathrm{cm} \\
\mathrm{mg} \cdot \mathrm{L}^{-1} \\
{ }^{\circ} \mathrm{C}\end{array}$ & $\begin{array}{l}0.3937 \\
1 \\
\left({ }^{\circ} \mathrm{C} \times 1.8\right)+32\end{array}$ \\
\hline
\end{tabular}


was seen in the $12-14-\mathrm{cm}$ bulbs $(4 \%)$ (Table 1). Percent flowering increased as bulb size increased. Bulb size had no effect on scape length, stem length, or inflorescence length (Table 2). The number of flowers per inflorescence increased from 78 to 100 as size increased from $14-16$ to $>18 \mathrm{~cm}$ (Table 2).

With 'Reuben', the greatest percent flowering was observed in the $>18-\mathrm{cm}$ bulbs $(100 \%)$, whereas the lowest percent flowering was observed with the smallest bulbs (Table l). Bulb size significantly affected scape length, stem length, inflorescence length, and number of flowers produced per inflorescence and each increased as bulb size increased.

Table 1. Bulb size effects on percentage of flowering in pineapple lily cultivars Megaru, Reuben, Tugela Gem, and Tugela Jade. Values are percentages of a single group of 25 bulbs per size class.

\begin{tabular}{llrcrr}
\hline & & \multicolumn{4}{c}{ Bulb circumference $(\mathbf{c m})^{\mathbf{z}}$} \\
\cline { 3 - 6 } Yr & Cultivar & $\mathbf{1 2 - 1 4}$ & $\mathbf{1 4 - 1 6}$ & $\mathbf{1 6 - 1 8}$ & $>\mathbf{1 8}$ \\
\hline 1 & Megaru & 4 & 32 & 96 & 100 \\
& Reuben & 64 & 96 & 96 & 100 \\
& Tugela Gem & 48 & 80 & 84 & 100 \\
2 & Megaru & 33 & 67 & 100 & 100 \\
& Reuben & 88 & 79 & 96 & 100 \\
& Tugela Jade & 57 & 36 & $\mathbf{5 2}$ & 88 \\
\hline
\end{tabular}

${ }^{\mathrm{z}} 1 \mathrm{~cm}=0.3937$ inch.

Table 2. Effect of bulb circumference on factors related to crop quality in pineapple lily cultivars Megaru, Reuben, and Tugela Gem (year 1).

\begin{tabular}{lcccc}
\hline $\begin{array}{l}\text { Bulb circumference } \\
(\mathbf{c m})^{\mathrm{z}}\end{array}$ & $\begin{array}{c}\text { Scape } \\
\text { length }(\mathbf{c m})\end{array}$ & $\begin{array}{c}\text { Stem length } \\
(\mathbf{c m})\end{array}$ & $\begin{array}{c}\text { Inflorescence } \\
\text { length }(\mathbf{c m})\end{array}$ & $\begin{array}{c}\text { Flowers (no. per } \\
\text { inflorescence })\end{array}$ \\
\hline & & - & 'Megaru' & - \\
$12-14$ & - & - & - & $78 \mathrm{c}^{\mathrm{y}}$ \\
$14-16$ & 47.0 & 26.8 & 22.3 & $90 \mathrm{~b}$ \\
$16-18$ & 52.5 & 30.1 & 21.0 & $100 \mathrm{a}$ \\
$>18$ & 51.4 & 28.6 & 22.6 & $<0.0001$ \\
Significance & $\mathrm{NS}$ & $\mathrm{NS}$ & $\mathrm{NS}$ & \\
& & & 'Reuben' & $55 \mathrm{~d}$ \\
$12-14$ & $39.3 \mathrm{c}$ & $26.6 \mathrm{c}$ & $12.6 \mathrm{~b}$ & $65 \mathrm{c}$ \\
$14-16$ & $43.3 \mathrm{c}$ & $29.6 \mathrm{~b}$ & $13.7 \mathrm{~b}$ & $77 \mathrm{~b}$ \\
$16-18$ & $47.2 \mathrm{~b}$ & $30.7 \mathrm{ab}$ & $16.8 \mathrm{a}$ & $102 \mathrm{a}$ \\
$>18$ & $51.7 \mathrm{a}$ & $32.7 \mathrm{a}$ & $18.6 \mathrm{a}$ & $<0.0001$ \\
Significance & $<0.0001$ & $<0.0001$ & $<0.0001$ & $62 \mathrm{c}$ \\
& & & 'Tugela Gem' & $70 \mathrm{c}$ \\
$12-14$ & 35.2 & 29.3 & $5.9 \mathrm{~b}$ & $87 \mathrm{~b}$ \\
$14-16$ & 36.5 & 27.9 & $8.5 \mathrm{ab}$ & $100 \mathrm{a}$ \\
$16-18$ & 36.6 & 28.4 & $8.2 \mathrm{ab}$ & $<0.0001$ \\
$>18$ & 37.6 & 27.6 & $10.4 \mathrm{a}$ & \\
Significance & $\mathrm{NS}$ & NS & 0.0309 &
\end{tabular}

${ }^{\mathrm{z}} 1 \mathrm{~cm}=0.3937$ inch.

${ }^{\mathrm{y}}$ Means followed by the same letter are not significantly different according to Tukey's honestly significant difference procedure at $\alpha=0.05$.

${ }^{\mathrm{x}}$ Indicates significance of analysis of variance.

Nonsignificant at $P \leq 0.05$. stem length, or inflorescence length but the number of flowers per inflorescence and number of leaves per plant increased as bulb size increased (Table 3).

With 'Reuben', the greatest percentage of flowering was observed in the $>18-\mathrm{cm}$ bulbs $(100 \%)$, whereas the lowest was observed in the 14-16$\mathrm{cm}$ bulbs (Table 1 ). Percent flowering generally increased as bulb size increased. Bulb size had no significant effect on stem length. Days to anthesis generally decreased as bulb size increased and scape length, inflorescence length, number of flowers per inflorescence, and number of leaves per bulb all increased as bulb size increased (Table 3).

In 'Tugela Jade', the greatest percent flowering was observed in the $>18-\mathrm{cm}$ bulbs $(88 \%)$, whereas the lowest percent flowering was observed in the $14-16-\mathrm{cm}$ bulb size group (Table 1). Bulb size did not significantly affect scape length or stem length but the inflorescence length, number of flowers per inflorescence, and number of leaves per plant all increased as bulb size increased. Time to anthesis for the $>18-\mathrm{cm}$ group was significantly less than for the 14-16- and 12-14-cm groups (Table 3 ).

\section{Discussion}

In many ornamental crops, the number of flowers produced per plant or inflorescence strongly influences crop quality and marketability. In geophytes, the size of the storage organ frequently plays a key role in controlling many quantitative aspects of flowering and final plant quality. For new cultivars and emerging ornamental geophyte crops, trials evaluating effects of storage organ size on crop quality and marketability are crucial to identifying the optimal storage bulb size for forcing. Luria et al. (1992) found monkshood (Aconitum napellus) marketability was heavily influenced by tuber size. The number of flowers per inflorescence increased more than 4-fold from the smallest to the largest tubers evaluated. Larger bulbs of cape cowslip (Lachenalia) produced larger plants with thicker stems and more numerous florets (Kapczynska, 2014). Similar effects were expected in the present work. 
Table 3. Effect of bulb circumference on factors related to crop quality in pineapple lily cultivars Megaru, Reuben, and Tugela Jade (year 2).

\begin{tabular}{|c|c|c|c|c|c|c|}
\hline Bulb circumference $(\mathrm{cm})^{\mathrm{z}}$ & $\begin{array}{c}\text { Time to } \\
\text { anthesis }(\mathrm{d})\end{array}$ & $\begin{array}{l}\text { Scape length } \\
(\mathrm{cm})\end{array}$ & $\begin{array}{l}\text { Stem length } \\
(\mathrm{cm})\end{array}$ & $\begin{array}{c}\text { Inflorescence } \\
\text { length }(\mathrm{cm})\end{array}$ & $\begin{array}{l}\text { Flowers (no. per } \\
\text { inflorescence) }\end{array}$ & $\begin{array}{c}\text { Leaves } \\
\text { (no.) }\end{array}$ \\
\hline & \multicolumn{6}{|c|}{ 'Megaru' } \\
\hline $12-14$ & 99 & 40.1 & 18.1 & 21.9 & $66 c$ & $5.0 \mathrm{~b}$ \\
\hline $14-16$ & 99 & 40.7 & 18.4 & 22.3 & $72 \mathrm{c}$ & $5.7 \mathrm{~b}$ \\
\hline $16-18$ & 98 & 40.6 & 18.4 & 22.2 & $84 \mathrm{~b}$ & $6.8 \mathrm{a}$ \\
\hline$>18$ & 97 & 38.0 & 17.0 & 21.0 & $98 \mathrm{a}$ & $7.3 \mathrm{a}$ \\
\hline $12-14$ & $99 \mathrm{a}$ & $35.8 \mathrm{~b}$ & 21.1 & $14.7 \mathrm{~b}$ & $69 c$ & $5.1 \mathrm{c}$ \\
\hline $14-16$ & $96 \mathrm{~b}$ & $38.6 \mathrm{ab}$ & 21.7 & $16.9 \mathrm{ab}$ & $85 \mathrm{~b}$ & $6.2 \mathrm{~b}$ \\
\hline $16-18$ & $95 \mathrm{~b}$ & $39.1 \mathrm{ab}$ & 21.9 & $17.3 \mathrm{a}$ & $89 \mathrm{ab}$ & $6.6 \mathrm{ab}$ \\
\hline$>18$ & $95 \mathrm{~b}$ & $39.7 \mathrm{a}$ & 21.7 & $18.8 \mathrm{a}$ & $96 a$ & $6.8 \mathrm{a}$ \\
\hline Significance & $<0.0001$ & $<0.0001$ & NS & $<0.0001$ & $<0.0001$ & $<0.0001$ \\
\hline$>18$ & $91 \mathrm{c}$ & 39.3 & 20.8 & $18.5 \mathrm{a}$ & $142 \mathrm{a}$ & $7.0 \mathrm{a}$ \\
\hline Significance & $<0.0001$ & NS & NS & 0.0306 & $<0.0001$ & $<0.0001$ \\
\hline
\end{tabular}

${ }^{\mathrm{z}} 1 \mathrm{~cm}=0.3937$ inch.

yndicates significance of analysis of variance.

${ }^{x}$ Means followed by the same letter are not significantly different according to Tukey's honestly significant difference procedure at $\alpha=0.05$.

Ns Nonsignificant at $P \leq 0.05$.

In the pineapple lily cultivars evaluated, percent flowering and overall crop quality was greatly influenced by bulb size. In both years, percent flowering exhibited a general increase as bulb size increased. With the exception of 'Tugela Jade', $>18-\mathrm{cm}$ bulbs of all cultivars exhibited 100\% inflorescence production. Bulb blindness (seemingly healthy plants not producing a viable inflorescence) was highly prevalent among 12-14- and 14-16-cm bulbs of all cultivars.

Bulb size had similar effects on the number of flowers produced per inflorescence, with the largest bulbs yielding the greatest number of flowers per inflorescence. The number of flowers produced per inflorescence strongly affected crop quality. Inflorescences of larger sized bulbs, bearing more flowers per inflorescence than their smaller counterparts, appeared fuller and more regularly shaped. Inflorescences produced by smaller bulbs, particularly those in the 12-14- and 14-16-cm bulb size groups, exhibited noticeable gaps between individual flowers and often appeared less vividly colored due to a lack of overlapping petals. Larger bulbs flowered faster for cultivars Reuben and Tegula Jade (Table 3), which was interesting given the larger bulbs also had one to two more leaves than smaller bulbs. Future work could more fully address this point and evaluate any deeper relationship, if any, of the number of leaves and forcing speed. A modest increase in stem length (year 1) and scape length (years 1 and 2) in 'Reuben' was observed as bulb size increased. Bulb size had no effect on scape length in the other cultivars evaluated. Inflorescence length increased as bulb size increased in all cultivars with the exception of Megaru. Although little variation in scape length was observed between bulb size groups, scapes produced by smaller bulbs were of poor quality because of their sparse, spindly appearance. Losses due to scapes toppling or excessive leaning were more common in the smaller bulb sizes (12-14 and 14-16 cm) than larger ones $(16-18$ and $>18 \mathrm{~cm})$, potentially because of smaller stem caliper (not measured). In 'Reuben' and 'Tugela Jade', larger bulbs flowered somewhat faster.

The data from these trials suggest that crop quality is uniformly highest when $>18-\mathrm{cm}$ bulbs are used in the greenhouse production of potted pineapple lily cultivars derived from tall pineapple lily and that using smaller bulbs may result in unacceptable crop losses due to bulb blindness or poor crop quality. Because 'Megaru' and 'Reuben' bulbs exhibited minimal bulb blindness in our trials, $16-18-\mathrm{cm}$ bulbs may be preferable to $>18-\mathrm{cm}$ bulbs if they can be obtained at lower cost. 'Tugela Jade' exhibited a high rate $(12 \%)$ of blindness even in the largest bulbs and may be less suitable for potted plant production.

\section{Literature cited}

Carlson, A. 2010. Developing water quality standards and production and postharvest protocols for specialty cut flowers. North Carolina State Univ., Raleigh, Master's Thesis.

De Hertogh, A. and M. Le Nard. 1993. The physiology of flower bulbs. Elsevier, Amsterdam, The Netherlands.

Kapczynska, A. 2014. Effect of bulb size on growth, flowering and bulb formation in Lachenalia cultivars. Hort. Sci. (Prague) 41:89-94.

Luria, G., A. Borochov, and A.A. Watad. 1992. Aconitum: Effect of tuber size, day length, and $\mathrm{GA}_{3}$ on growth, flowering, and tuber production. Acta Hort. 325:113-117. 